\title{
Clinical and microbial evaluation of dental scaling associated with subgingival minocycline in chronic periodontitis subjects
}

\section{Avaliação clínica e microbiana da raspagem dental associada à minociclina subgengival em indivíduos com periodontite crônica}

\author{
Silvia Maria Rodrigues Querido* \\ Sheila Cavalca Cortelli** \\ Marcelo Werneck Barata de Araújo*** \\ José Roberto Cortelli****
}

\begin{abstract}
The aims of this double-blind randomized clinical trial were to evaluate the presence of periodontal pathogens and the clinical response of periodontal pockets treatment to scaling and root planing (SRP) associated with subgingival minocycline (SM). A total of 36 subjects, 26 to 60 years old $(40.7 \pm 9.1)$, who had been previously diagnosed with chronic periodontitis, were included in the present study. Eighteen subjects were selected for the test group (TG), who were treated with SRP plus SM (new treatment), and 18 subjects for the control group (CG) who received SRP plus vehicle (current treatment). Two homologous sites in each subject with a probing depth (PD) $\geq 6 \mathrm{~mm}$ were chosen. To evaluate the clinical response after treatment, PD was measured at baseline and at 90 days. Microbiological evaluation was performed to detect 7 periodontal pathogens using polymerase chain reaction at baseline, 30, and 120 days. A mean reduction in PD of 2.8 and $2.1 \mathrm{~mm}$ was observed in the TG and CG, respectively. At baseline, $P$. gingivalis was the most prevalent organism in both test (65.8\%) and control (48.6\%) groups. After 120 days it fell to $30.8 \%$ in TG and to $23.1 \%$ in CG. There were no statistically significant differences between the test and control groups concerning PD ( $p>0.05$ by Wilcoxon test) or presence of periodontal pathogens ( $p>0.05$ by Wilcoxon and chi-square; $p>0.01$ by Signal test). The results observed showed that the new treatment was as effective as the current treatment in reducing periodontal pathogens and PD among chronic periodontitis subjects.
\end{abstract}

DESCRIPTORS: Bacteria; Dental scaling; Minocycline.

\begin{abstract}
RESUMO: O objetivo deste estudo randomizado duplo-cego foi avaliar a presença de periodontopatógenos e o comportamento clínico de bolsas periodontais tratadas com raspagem e aplainamento radicular (RAR) associado à minociclina subgengival (MS). Foram incluídos no presente estudo 36 indivíduos de 26 a 60 anos de idade $(40,7 \pm 9,1)$, previamente diagnosticados com periodontite crônica. Dezoito indivíduos foram selecionados para o grupo teste (GT), tratado com RAR e MS (novo tratamento), e 18 indivíduos, para o grupo controle (GC), que recebeu RAR e veículo (tratamento convencional). Foram selecionados dois sítios homólogos em cada indivíduo com profundidade de sondagem (PS) $\geq 6 \mathrm{~mm}$ para testar a hipótese proposta. Para avaliar o comportamento clínico após o tratamento, a mensuração da PS foi realizada inicialmente e após 90 dias. A avaliação microbiana foi realizada para detecção de 7 periodontopatógenos através de reação em cadeia da polimerase, inicialmente e após 30 e 120 dias. Observou-se redução média de 2,8 e 2,1 mm na PS nos grupos teste e controle, respectivamente. Inicialmente, $P$. gingivalis foi o microrganismo mais prevalente tanto no GT (65,8\%) quanto no GC (48,6\%). Após 120 dias, houve redução para $30,8 \%$ no GT e $23,1 \%$ no GC. Não houve diferenças estatisticamente significativas entre os grupos em relação à PS (teste Wilcoxon - p >0,05) e presença dos periodontopatógenos (teste Wilcoxon e qui-quadrado - $p>0,05$ e teste do sinal - $p>0,01$ ). Os resultados observados demonstraram que o novo tratamento foi tão efetivo quanto o tratamento convencional na redução de periodontopatógenos e de PS em indivíduos com periodontite crônica.
\end{abstract}

DESCRITORES: Bactérias; Raspagem dentária; Minociclina.

\section{INTRODUCTION}

Periodontitis is a multi-factorial disease with microbial dental plaque as the initiator of peri- odontal disease. However, the manifestation and progression of periodontitis is influenced by a wide

\footnotetext{
* Research Assistant, Dental Research and Graduate Studies Division; **Assistant Professor, Microbiology and Periodontics Research and Graduate Studies Division, Department of Dentistry; ****Professor and Chairman, Preventive Dentistry and Periodontics Research and Graduate Studies Division, Department of Dentistry - University of Taubaté.

*** Assistant Professor, Dental Research and Graduate Studies Division, Department of Periodontology, Guarulhos University.
} 
Querido SMR, Cortelli SC, Araújo MWB, Cortelli JR. Clinical and microbial evaluation of dental scaling associated with subgingival minocycline in chronic periodontitis subjects. Braz Oral Res 2004;18(2):110-5.

variety of determinants and factors including subject characteristics, social and behavioral factors, systemic factors, genetic factors, tooth-level factors, microbial composition of dental plaque and other emerging risk factors ${ }^{12}$.

There is plenty of evidence that over 300 different species of bacteria are recognized in the oral cavity, but only a few are directly associated with periodontal disease ${ }^{11}$. These include $P$. gingivalis, $P$. intermedia, $A$. actinomycetemcomitans, $T$. forsythensis (formerly B. forsythus), F. nucleatum, Selenomona species, C. rectus and E. corrodens ${ }^{18}$.

Mechanical therapy (scaling and root planing) aimed at the removal of pathogens and their products, has been shown to be effective in reducing bacterial colonization to sub-threshold values, in order to control the progression of periodontal disease (current treatment). However, scaling and root planing (SRP) may not eradicate species that have invasive properties, i.e., bacterial species that can reach epithelial cells and subepithelial connective tissues of the periodontium ${ }^{1}$, leading to the use of antimicrobial agents, which may help to eliminate the pathogens ${ }^{3}$.

Several locally delivered antimicrobial agents currently used are designed to enhance the healing process and improve periodontal health. In diseased sites that are more difficult to control, the application of local drug delivery devices may be a valid approach for treating infected sites ${ }^{9}$.

However, research has focused on the development of a new treatment to appropriately deliver the drug into the periodontal pockets. For instance, a method of microencapsulating minocycline hydrochloride in a bioabsorbable polymer (polyglycolide-co-dl-lactide) has been developed, resulting in microspheres that are administered into sites with periodontal disease ${ }^{22}$.

The aim of this study was to evaluate the presence of periodontal pathogens and the clinical response to SRP periodontal pocket treatment associated with subgingival minocycline (SM) in chronic periodontitis subjects.

\section{MATERIALS AND METHODS}

Thirty-six subjects with generalized severe chronic periodontitis were recruited to participate in this double-blind randomized clinical trial, after informed consent (Institutional Committee on Research Involving Human, protocol n. 013/02) was obtained from each subject. To be included in the study, subjects had to meet requirements for inclusion (non-treated chronic periodontitis, and patient had to be in good general health) and exclusion criteria (according to Cortelli et al. ${ }^{8}, 2003$ ).

At baseline, periodontal and radiographic examinations determined the periodontal status of all subjects, based on the criteria presented by the American Academy of Periodontology ${ }^{2}$ (1999). During the periodontal examination, one trained, calibrated examiner measured periodontal probing depth (PD) at 6 sites per tooth, using a manual periodontal probe (PQWBR - Hu Friedy Mfg. Inc. Chicago, IL, USA). The reproducibility of these measurements were analyzed using kappa statistics, and obtained kappa $=0.83$. Two homologous sites with $\mathrm{PD} \geq 6 \mathrm{~mm}$ without furcation involvement were selected from each subject to test the hypothesis proposed. After randomization, two groups were formed; one considered a test group (SRP plus SM) and one a control group (SRP plus vehicle). All subjects were examined at baseline and at 90 days for measurement of PD. In addition, a trained examiner evaluated supragingival plaque control (Oral Hygiene Index - $\mathrm{OHI}^{13}$ ) and oral hygiene compliance at baseline and at 90 days.

Subgingival samples were taken from each of the two sites from each subject using sterile paper points (Tanari, Tanariman Industrial Ltda., Manacapuru, Brazil) inserted to the depth of the pockets after the removal of supragingival plaque. Paper points were removed after 15 seconds, and immediately placed in phosphate-buffered saline (Promega, Madison, WI, USA) (pH 7.4) on ice. These microbiological samples were collected at baseline, 30 , and 120 days.

The samples in phosphate-buffered saline $(\mathrm{pH} 7.4)$ were warmed to $37^{\circ} \mathrm{C}$ for 10 minutes and were thoroughly mixed on a vortex mixer (PRO Scientific Inc., Oxford, UK); $0.2 \mathrm{ml}$ of the microbial suspension was washed 3 times with distilled water. Then the bacterial pellets were resuspended in $0.1 \mathrm{ml}$ of distilled water, boiled for 10 minutes, and placed on ice. After centrifugation to remove cell debris, the supernatant was used for polymerase chain reaction (PCR) analysis. Briefly, $5 \mu 1$ of the sample was added to $45 \mu 1$ of reaction mixture containing $5 \mu$ of 10 X PCR buffer (Promega, Madison, WI, USA), 1.25 unit of Taq DNA polymerase (Promega, Madison, WI, USA), and $0.2 \mathrm{~mm}$ of each deoxyribonucleotides (Pharmacia LKB, Piscataway, NJ, USA). PCR amplification was performed using a thermalcycler (Perkin Elmer Cetus, Wellesley, MA, USA). The primer sequences and the PCR procedure were previously described with details by 
Querido SMR, Cortelli SC, Araújo MWB, Cortelli JR. Clinical and microbial evaluation of dental scaling associated with subgingival minocycline in chronic periodontitis subjects. Braz Oral Res 2004;18(2):110-5.

Avila-Campos et al. ${ }^{4}$ (1999) (F. nucleatum), Saiki et al. ${ }^{14}$ (1988) (T. forsythensis, C. rectus, E. corrodens, $P$. gingivalis and $P$. intermedia) and Cortelli et al. ${ }^{8}$ (2003) (A. actinomycetemcomitans).

PCR products were analyzed using $1.5 \%$ agarose gel (Sigma, Dorset, UK) electrophoresis performed at $4 \mathrm{~V} / \mathrm{cm}$ in tris-acetate EDTA buffer (Promega, Madison, WI, USA). The gel was stained with $0.5 \mu \mathrm{g} / \mathrm{ml}$ ethidium bromide (Amershan, Airlington Heights, USA) and photographed under $300 \mathrm{~nm}$ ultraviolet light.

Each subject received local anesthesia followed by full-mouth SRP both supra- and subgingivally according to individual needs. Following SRP, the test group was treated with minocycline microspheres (Arestin ${ }^{\mathrm{TM}}$, OraPharma, Inc., Warmister, PA, USA), while the control group was treated with vehicle (polymer without minocycline - Byofórmula, manipulation pharmacy, São Paulo, Brazil).

The microspheres were dispensed subgingivally to the base of the periodontal pocket by means of a disposable plastic cartridge (OraPharma Inc., Warmister, PA, USA) affixed to a stainless-steel handle. Each cartridge contains $1 \mathrm{mg}$ of minocycline microencapsulated in Poly (glycolie-co dllactide) dry powder and it is enough for one periodontal pocket. At 90 days, test and control groups received an additional application of the assigned treatment.

\section{Statistical analysis}

Sample size calculation was performed using the PS - Power Sample Size program (Biostat, Englewood, NJ, USA), version 2.1.30. The sample size of 36 subjects was reached when $\alpha=0.05$, power $=0.80$, and an initial difference between mean pocket depth of $0.1 \mathrm{~mm}$ among groups, and a $1: 1$ proportion of subjects in each group were established.

The changes between the baseline and the 90-day measurement of PD for test and control groups were examined by Wilcoxon test $(\mathrm{p}<0.05)$. Differences in the OHI scores between groups and exams were analyzed by analysis of variance, Newman-Keuls and HSD - Tukey (Honest Significant Differences) tests $(\mathrm{p}<0.05)$. The prevalence of each pathogen at baseline, 30, and 120 days was analyzed by Wilcoxon test $(\mathrm{p}<0.05)$. The proportional distribution of the bacteria between test and control groups was analyzed by Signal test $(\mathrm{p}<0.01)$. In addition, a chi-square test was used to determine a positive association between two bacterial species $(\mathrm{p}<0.05)$.

\section{RESULTS}

Thirty-six subjects (17 female and 19 male), aged 26 to 60 years old (mean $40.7 \pm 9.1$ ), participated in the present study. Data related to the mean of PD indicates that, at baseline, the values for test and control groups were not different, $7.8 \pm 0.9 \mathrm{~mm}$ and $7.9 \pm 0.8 \mathrm{~mm}$, respectively. After 90 days, the mean of $\mathrm{PD}$ decreased to $5.0 \pm 1.4 \mathrm{~mm}$ among test group, and $5.8 \pm 2.1 \mathrm{~mm}$ for the control group. The results did not show a statistically significant difference between the test and the control groups ( $p>0.05$ by Wilcoxon test).

Median values of the OHI scores were $93.5 \%$ for the test group and $95.5 \%$ for the control group at baseline, and after 90 days it decreased to $67.5 \%$ and $72.0 \%$ respectively for the test and control groups. A statistically significant difference was observed between baseline and 90 days for the $\mathrm{OHI}$ scores within each of the groups. However, when the difference between the test and control groups was investigated, no statistically significant differences were observed between each time point.

The prevalence of analyzed bacteria present in the 36 subjects, for the test and control groups at baseline, 30, and 120 days is indicated in Table 1 . In the test group, the prevalence of A. actinomycetemcomitans $(\mathrm{p}=0.01), P$. gingivalis $(\mathrm{p}=0.00)$ and $T$. forsythensis $(\mathrm{p}=0.02)$ significantly decreased after 120 days $(\mathrm{p}<0.05)$. There was a significant increase in $F$. nucleatum $(p=0.01)$. The prevalence of bacterial species was higher among test than among controls at all three time-points. However, data indicated that prevalence decreased as time increased. At baseline, prevalence of bacteria ranged from 22.9 - $65.8 \%$ among the test group, and from 11.5 - 48.6\% among controls. At 30 days, the prevalence among the test group ranged from $14.9-37.1 \%$ and from $14.9 \%-33.4 \%$ among controls. At 120 days, bacterial prevalence among the test group had increased, compared to the 30-day time point (range: $15.4-46.2 \%$ ). However, the values were still below the levels observed at baseline. Among controls, prevalence at 120 days was lower than at the two previous time-points, ranging from $7.7 \%$ to $30.8 \%$.

The Signal test did not show significant differences in the proportional distributions of periodontal pathogens between the test and control groups $(\mathrm{p}>0.01)$.

The correlation between bacterial species was investigated in test and control groups (Figure 1). Positive associations were found between A. acti- 
Querido SMR, Cortelli SC, Araújo MWB, Cortelli JR. Clinical and microbial evaluation of dental scaling associated with subgingival minocycline in chronic periodontitis subjects. Braz Oral Res 2004;18(2):110-5.

TABLE 1 - Prevalence (\%) and distribution of periodontal pathogens among test and control groups (n = 36).

\begin{tabular}{l|c|c|c|c|c|c}
\hline \multirow{2}{*}{ Bacteria } & \multirow{2}{*}{ Time } & \multicolumn{2}{|c|}{ Baseline } & \multicolumn{2}{|c}{30 days } & \multicolumn{2}{c}{120 days } \\
\cline { 2 - 7 } & Test & Control & Test & Control & Test & Control \\
\hline A. actinomycetemcomitans & 34.3 & 20.0 & 33.4 & 18.6 & $15.4^{*}$ & 15.4 \\
\hline P. gingivalis & 65.8 & 48.6 & $37.1^{*}$ & $33.4^{*}$ & $30.8^{*}$ & $23.1^{*}$ \\
\hline$P$. intermedia & 28.6 & 20.0 & 22.3 & $29.7^{*}$ & 23.1 & 15.4 \\
\hline T. forsythensis & 31.5 & 28.6 & 22.3 & $26.0^{*}$ & $15.4^{*}$ & $7.7^{*}$ \\
\hline C. rectus & 25.8 & 11.5 & 22.3 & 14.9 & 15.4 & 15.4 \\
\hline E. corrodens & 22.9 & 20.0 & $14.9^{*}$ & 33.4 & 30.8 & 23.1 \\
\hline F. nucleatum & 22.9 & 31.5 & $14.9^{*}$ & $18.6^{*}$ & $46.2^{*}$ & 30.8 \\
\hline \hline
\end{tabular}

*Statistically significant difference $(\mathrm{p}<0.05)-$ Wilcoxon test.

FIGURE 1 - Chi-square test of associations among examined species in test and control groups at baseline, 30, and 120 days.

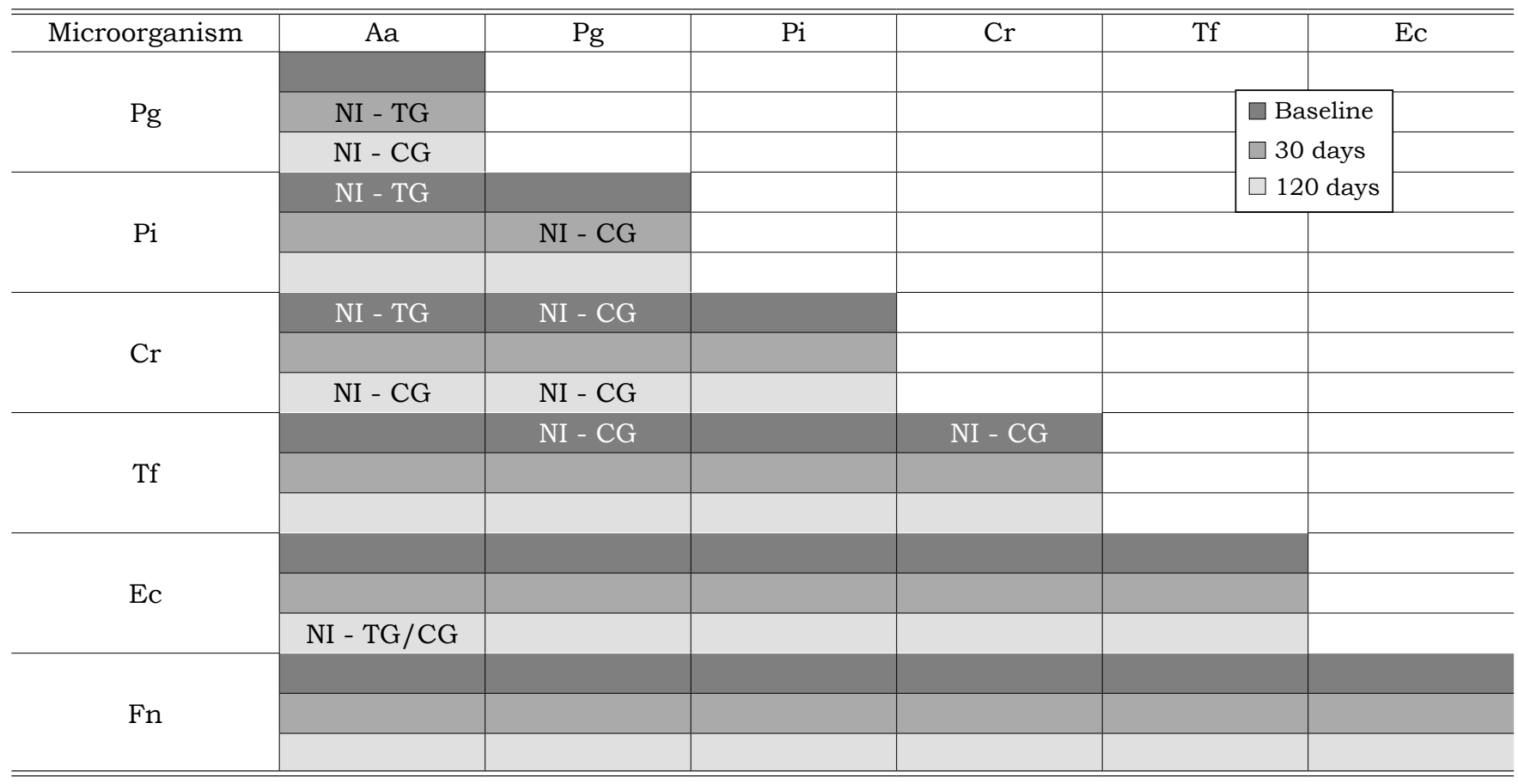

$\mathrm{NI}=$ not-independent $; \mathrm{TG}=$ Test group $; \mathrm{CG}=$ Control group. $\mathrm{Aa}=A$. actinomycetemcomitans; $\mathrm{Pg}=P$. gingivalis $; \mathrm{Pi}=P$. intermedia; $\mathrm{Cr}=C$. rectus; $\mathrm{Fn}=F$. nucleatum; $\mathrm{Ec}=E$. corrodens; $\mathrm{Tf}=T$. forsythensis .

nomycetemcomitans and $P$. intermedia $(\mathrm{p}=0.0049$, $\left.\chi^{2}=7.93\right)$, A. actinomycetemcomitans and $C$. rectus $\left(\mathrm{p}=0.0176, \chi^{2}=5.64\right)$, A. actinomycetemcomitans and $P$. gingivalis $\left(\mathrm{p}=0.0485, \chi^{2}=3.89\right)$, and $A$. actinomycetemcomitans and E. corrodens $(\mathrm{p}=0.0211$, $\left.\chi^{2}=5.32\right)$, all in the test group.

Among controls, statistically significant positive associations were found between $P$. gingivalis and $C$. rectus $\left(\mathrm{p}=0.0288, \chi^{2}=4.78\right.$ and $\mathrm{p}=0.0050, \chi^{2}=7.88$ at baseline and at 120 days, respectively); $P$. gingivalis and $T$. forsythen- sis $\left(\mathrm{p}=0.0186, \chi^{2}=5.54\right) ; C$. rectus and $T$. forsythensis $\left(\mathrm{p}=0.0290, \chi^{2}=4.77\right) ; P$. gingivalis and $P$. intermedia $\left(\mathrm{p}=0.0370, \chi^{2}=4.35\right) ;$ A. actinomycetemcomitans and $P$. gingivalis $(\mathrm{p}=0.0050$, $\left.\chi^{2}=7.88\right)$; and A. actinomycetemcomitans and $C$. rectus $\left(\mathrm{p}=0.0003, \chi^{2}=13.00\right)$.

\section{DISCUSSION}

Mechanical therapy is usually the first mode of treatment recommended for most periodontal 
Querido SMR, Cortelli SC, Araújo MWB, Cortelli JR. Clinical and microbial evaluation of dental scaling associated with subgingival minocycline in chronic periodontitis subjects. Braz Oral Res 2004;18(2):110-5.

infections, as the mean probing depth reduction ranges from 0.03 in pocket depths between 1-3 $\mathrm{mm}$, to $2.16 \mathrm{~mm}$ in pocket depths greater than $6 \mathrm{~mm}^{7}$. In scientific investigations, probing depth is a method frequently used to evaluate both treatment and disease progression ${ }^{21}$. Badersten et al. ${ }^{5}$ (1984) showed a reduction in probing depth of approximately $2.3 \mathrm{~mm}$ in a study of nonsurgical therapy of subjects with advanced chronic periodontitis. The results of this study are in agreement with the previous literature, as subjects in both groups responded favorably to initial treatment, with a reduction in PD of $2.9 \mathrm{~mm}$ among test and $2.4 \mathrm{~mm}$ among control groups.

In the present study, there were no significant differences between test and control groups with regard to probing depth. Likewise, Timmerman et al. ${ }^{19}(1996)$ showed no additional benefit in probing depth when SRP was associated with SM, compared to controls.

It has been shown that the root surface itself harbors viable bacteria that may provide niches for subgingival bacterial recolonization ${ }^{1,10}$. The root may become a bacterial reservoir from which periodontal pathogenic bacteria can recolonize previously treated pockets and contribute to the failure of therapy or the recurrence of the disease ${ }^{6}$. The present study analyzed the presence of periodontal pathogens at 30 and 120 days, time points established on the attempt to evaluate possible microbial recolonization, always 30 days after the subgingival administration of minocycline. Sbordone et al. ${ }^{15}$ (1990) suggested that the microbiota might reestablish itself within 40-60 days following subgingival debridement with poor supragingival plaque control. Deep pockets are particularly difficult to control, since recolonization of the subgingival microbiota occurs at around 120-240 days, despite meticulous supragingival plaque control and multiple sessions of subgingival debridement ${ }^{9}$. The subjects enrolled in our study received oral hygiene instructions and were closely followed by a trained examiner who evaluated plaque control and oral hygiene compliance. Despite the close plaque control, some of the severely periodontallyinvolved participants of the present study showed a similar pattern of recolonization previously observed by other investigators.

$P$. gingivalis in our study was the most prevalent bacteria both in the test $(65.8 \%)$ and control $(48.6 \%)$ groups at baseline. This bacteria was found in a high percentage in the test and control groups after 30 (37.1\% and 33.4\%, respectively) and 120 days $(30.8 \%$ and $23.1 \%$, respectively). $P$. gingivalis has been considered as one of the most important pathogens in advanced periodontitis based on its high prevalence in progressive periodontitis lesions ${ }^{16,17}$. After 30 days, the prevalence of only $P$. intermedia, $C$. rectus and E. corrodens increased in the control group. A reduction in bacterial prevalence was observed in all species except for $C$. rectus, $E$. corrodens and $F$. nucleatum, which did not decrease after 120 days. The PCR method was used to characterize not only the specific bacterial types, but also the possible intercorrelations that may occur. The results of the present study confirm that the studied bacterial correlations do not follow a unique pattern. These results may be of use in the explanation of bacterial interassociation, one of the objectives of molecular biology. The present study also demonstrated no significant statistical differences between the test and control groups with regard to microbiological parameters. The high sensitivity of PCR may partially explain these findings, and the differences in the microbial profiles could be observed if a quantitative microbiological instead of a PCR approach had been chosen. Similarly, Timmerman et al. ${ }^{19}$ (1996) showed a significant reduction in the prevalence of periodontal pathogens over a 15-month period, but no significant reduction was observed when local delivery of minocycline was used.

In contrast, van Steenberghe et al. ${ }^{20}$ (1999) demonstrated that SM as an adjunct to SRP resulted in the reduction of $P$. gingivalis, $P$. intermedia, C. rectus, E. corrodens, $F$. nucleatum and $T$. denticola, a reduction in PD greater than that seen in the control. Although this study protocol ${ }^{20}$ did not allow optimal oral hygiene instruction and reinforcement, this was emphasized in the present study.

Williams et al. ${ }^{22}$ (2001) reported that SRP plus SM was effective in reducing PD in chronic periodontitis individuals as shown in the present study. However, their results demonstrated that adjunctive therapy with minocycline microspheres provided significantly greater $\mathrm{PD}$ reduction than SRP alone.

In the past 15 years, there has been an emergence of a range of adjunctive antimicrobial regimens designed to aid the mechanical methods of dealing with subgingival plaque. To achieve a reduction or elimination of pathogens, a subgingival application of antiseptics and/or antibiotics has often been considered, but subjects enrolled in the present study did not benefit from local delivery of 
Querido SMR, Cortelli SC, Araújo MWB, Cortelli JR. Clinical and microbial evaluation of dental scaling associated with subgingival minocycline in chronic periodontitis subjects. Braz Oral Res 2004;18(2):110-5.

minocycline. However, subgingival debridement in combination with oral hygiene instruction by itself has been shown to be an effective treatment.

\section{CONCLUSION}

In conclusion, the results of this double-blind randomized clinical trial indicated that SRP associated with SM (new treatment) was as effective as mechanical therapy alone (current treatment) in reducing both the prevalence of periodontal patho-

\section{REFERENCES}

1. Adriaens PA, de Boever JA, Loesche WJ. Bacterial invasion in root cementum and radicular dentin of periodontally diseased teeth in humans. J Periodontol 1988;59(4):22230.

2. American Academy of Periodontology. Ann Periodontol 1999;4(1):1-6.

3. American Academy of Periodontology. The role of controlled drug delivery for periodontitis. J Periodontol 2000;71(1):125-40.

4. Avila-Campos MJ, Sacchi CT, Whitney AM, Steigerwart AG, Mayer LW. Arbitrarily primed-PCR for identification and epidemiologic subtyping of oral isolates of $F$. nucleatum. J Periodontol 1999;70(10):1202-8.

5. Badersten A, Nilveus R, Egelberg J. Effect of nonsurgical periodontal therapy. II. Severely advanced periodontitis. J Clin Periodontol 1984;11(1):63-76.

6. Bollen CML, Mongardini C, Papaioannow W, van Steenberghe D, Quirynen M. The effect of a one-stage-fullmouth disinfection on different intra-oral niches. Clinical and microbiological observations. J Clin Periodontol 1998;25(1):56-66.

7. Cobb CM. Non-surgical pocket therapy: mechanical. Ann Periodontol 1996;1:443-90.

8. Cortelli SC, Jorge AOC, Cortelli JR, Jordan SF, Haraszthy VI. Detection of highly and minimally leukotoxic A. actinomycetemcomitans strains in patients with periodontal disease. Pesqui Odontol Bras 2003;17(2):183-8.

9. Drisko $\mathrm{CH}$. Nonsurgical periodontal therapy. Periodontol $20002001 ; 25: 77-88$.

10. Giulianna G, Ammatuna P, Pizzo G, Capone F, D'Angelo $\mathrm{M}$. Occurrence of invading bacteria in radicular dentin of periodontally diseased teeth: microbiological findings. J Clin Periodontol 1997;24(7):478-85.

11. Moore WEC, Moore LVH. The bacteria of periodontal diseases. Periodontol 2000 1994;5:66-77.

12. Nunn ME. Understanding the etiology of periodontitis: an overview of periodontal risk factors. Periodontol 2000 2003;32:11-23.

13. O'Leary TJ, Drake RB, Naylor JE. The plaque control record. J Periodontol 1972;43(1):38. gens and probing depth in chronic periodontitis subjects.

\section{ACKNOWLEDGMENT}

The authors would like to thank Heather Ochs-Balcom, PhD, from the Department of Social and Preventive Medicine of the State University of New York at Buffalo, for her critical reading of the manuscript.

14. Saiki RK, Geldand DH, Stoffel S, Scharf SJ, Higuchi $\mathrm{R}$, Horn GT, et al. Primer-mediated enzymatic amplification of DNA with a thermo stable DNA polymerase. Science 1988;239:487-91.

15. Sbordone L, Ramaglia L, Guletta E, Iacono V. Recolonization of the subgingival microflora after scaling and root planing in human periodontitis. J Periodontol 1990;61(9):579-84.

16. Slots J, Bragd L, Wikström M, Dahlén G. The occurrence of Actinobacillus actinomycetemcomitans, Bacteroides gingivalis and Bacteroides intermedius in destructive periodontal disease in adults. J Clin Periodontol 1986;13(6):570-7.

17. Slots J, Listgarten MA. Bacteroides gingivalis, Bacteroides intermedius and Actinobacillus actinomycetemcomitans in human periodontal diseases. J Clin Periodontol 1988;15(2):85-93.

18. Slots J, Rams TE. Microbiology of periodontal diseases. In: Slots J, Taubman MA (ed). Contemporary oral microbiology and immunology. St. Louis: CV Mosby Co.; 1992. p. 425-43.

19. Timmerman MF, van der Weijden GA, van Steenbergen TJM, Mantel MS, de Graaff J, van der Velden U. Evaluation of the long-term efficacy and safety of locallyapplied minocycline in adult periodontitis patients. J Clin Periodontol 1996;23(8):707-16.

20. van Steenberghe D, Rosling B, Söder PO, Landry RG, van der Velden U, Timmerman MFT, et al. A 15-month evaluation of the effects of repeated subgingival minocycline in chronic adult periodontitis. J Periodontol 1999;70(6):65767.

21. Villata L, Baelum V. Reproducibility of attachment level recordings using an electronic and a conventional probe. J Periodontol 1996;67(12):1292-300.

22. Williams RC, Paquette DW, Offenbacher S, Adams $\mathrm{DF}$, Armitage GC, Bray K, et al. Treatment of periodontitis by local administration of minocycline microspheres: a controlled trial. J Periodontol 2001;72(11):1535-44.

Received for publication on Nov 04, 2003

Sent for alterations on Feb 11, 2004 Accepted for publication on May 10, 2004 